\title{
The role of Phragmites in the $\mathrm{CH}_{4}$ and $\mathrm{CO}_{2}$ fluxes in a minerotrophic peatland in southwest Germany
}

\author{
Merit van den Berg, Joachim Ingwersen, Marc Lamers, and Thilo Streck \\ Institute of Soil Science and Land Evaluation, University of Hohenheim, Stuttgart, Germany \\ Correspondence to: Merit van den Berg (merit.vandenberg@uni-hohenheim.de)
}

Received: 4 April 2016 - Published in Biogeosciences Discuss.: 7 April 2016

Revised: 22 September 2016 - Accepted: 23 September 2016 - Published: 9 November 2016

\begin{abstract}
Peatlands are interesting as a carbon storage option, but are also natural emitters of the greenhouse gas methane $\left(\mathrm{CH}_{4}\right)$. Phragmites peatlands are particularly interesting due to the global abundance of this wetland plant (Phragmites australis) and the highly efficient internal gas transport mechanism, which is called humidity-induced convection (HIC). The research aims were to (1) clarify how this plant-mediated gas transport influences the $\mathrm{CH}_{4}$ fluxes, (2) which other environmental variables influence the $\mathrm{CO}_{2}$ and $\mathrm{CH}_{4}$ fluxes, and (3) whether Phragmites peatlands are a net source or sink of greenhouse gases. $\mathrm{CO}_{2}$ and $\mathrm{CH}_{4}$ fluxes were measured with the eddy covariance technique within a Phragmites-dominated fen in southwest Germany. One year of flux data (March 2013-February 2014) shows very clear diurnal and seasonal patterns for both $\mathrm{CO}_{2}$ and $\mathrm{CH}_{4}$. The diurnal pattern of $\mathrm{CH}_{4}$ fluxes was only visible when living, green reed was present. In August the diurnal cycle of $\mathrm{CH}_{4}$ was the most distinct, with 11 times higher midday fluxes $\left(15.7 \mathrm{mg} \mathrm{CH}_{4} \mathrm{~m}^{-2} \mathrm{~h}^{-1}\right)$ than night fluxes $\left(1.41 \mathrm{mg} \mathrm{CH}_{4} \mathrm{~m}^{-2} \mathrm{~h}^{-1}\right.$ ). This diurnal cycle has the highest correlation with global radiation, which suggests a high influence of the plants on the $\mathrm{CH}_{4}$ flux. But if the cause were the HIC, it would be expected that relative humidity would correlate stronger with $\mathrm{CH}_{4}$ flux. Therefore, we conclude that in addition to HIC, at least one additional mechanism must be involved in the creation of the convective flow within the Phragmites plants. Overall, the fen was a sink for carbon and greenhouse gases in the measured year, with a total carbon uptake of $221 \mathrm{~g} \mathrm{C} \mathrm{m}^{-2} \mathrm{yr}^{-1}$ ( $26 \%$ of the total assimilated carbon). The net uptake of greenhouse gases was $52 \mathrm{~g} \mathrm{CO}_{2}$ eq. $\mathrm{m}^{-2} \mathrm{yr}^{-1}$, which is obtained from an uptake of $\mathrm{CO}_{2}$ of $894 \mathrm{~g} \mathrm{CO}_{2}$ eq. $\mathrm{m}^{-2} \mathrm{yr}^{-1}$ and a release of $\mathrm{CH}_{4}$ of $842 \mathrm{~g} \mathrm{CO}_{2}$ eq. $\mathrm{m}^{-2} \mathrm{yr}^{-1}$.
\end{abstract}

\section{Introduction}

Approximately one-third of the world's soil carbon is stored in peatlands, although they cover only $3 \%$ of earth's total land surface (Lai, 2009). Therefore, peatland conservation or restoration as a climate change mitigation option has recently gained much attention (Bonn et al., 2014). Apart from the positive effect of carbon storage, peatlands are also natural emitters of methane. Methane is a 28 times stronger greenhouse gas than carbon dioxide when calculated over a 100-year cycle (IPCC, 2013). Estimates of methane emissions from peatlands range between $30-50 \mathrm{Tg} \mathrm{yr}^{-1}$ worldwide (Roulet, 2000). There is a high variation in methane emissions. This variability, however, and all underlying processes are not yet well understood (Hendriks et al., 2010; Segers, 1998). It is therefore essential to gain more knowledge about the role of methane in the greenhouse gas budgets of peatlands.

In wetland ecosystems, methane can be transported from the soil to the atmosphere via diffusion, ebullition and via aerenchyma of roots and stems of vascular plants (Moore, 1994; Le Mer and Roger, 2001; Hendriks et al., 2010). The largest part of the methane produced in peatlands is directly oxidized in the soil (Le Mer and Roger, 2001; Brix et al., 2001; Lai, 2009). The extent of oxidation depends on the gas transport pathway and is highly dependent on the position of the water table (Moore, 1994; Le Mer and Roger, 2001; Brix et al., 2001; Lai, 2009) and the presence of vascular wetland plants (Grünfeld and Brix, 1999; Hendriks et al., 2010). Compared to other wetland plants, Phragmites australis (common reed) appears to have a high ability in transporting gases between the soil and atmosphere (Salhani and Stengel, 2001). 
The gas exchange within Phragmites plants takes place via convective flow through the culm. Currently, it is believed that this transport originates from creating a humidityinduced pressure gradient between the internal culm and the atmosphere (Armstrong and Armstrong, 1990, 1991; Armstrong et al., 1996b; Afreen et al., 2007). The pores (stomata) in the leaf sheaths of Phragmites are more resistant to pressure flow than against gas diffusion. Due to the higher humidity in the internal culm of the reed, $\mathrm{O}_{2}$ and $\mathrm{N}_{2}$ concentrations inside the plant are diluted. Therefore, $\mathrm{O}_{2}$ and $\mathrm{N}_{2}$ are transported along the concentration gradient from the atmosphere into the sheaths and a higher pressure is created. This causes an airflow from the green living reed stems to the rhizomes and goes back to the atmosphere via dead or broken stems that are still connected to the rhizomes. This mechanism is more than 5 times as efficient as diffusion (Brix et al., 2001) and is also found in other wetland plants (e.g. Nuphar, Eleocharis, Nelumbo and Typha) that have a submerged rhizome system (Dacey and Klug, 1979; Dacey, 1987; Brix et al., 1992a; Bendix et al., 1994). In a Phragmites-dominated wetland, $70 \%$ of the methane produced is transported through the plants (Brix, 1989). This means that methane emissions should be highly dependent on this transport mechanism. Apart from this potential influence of humidity-induced convection (HIC) on methane fluxes, Phragmites wetlands can also accrete large amounts of carbon in the soil due to the high annual primary production compared to other wetland plants (Brix et al., 2001; Zhou et al., 2009).

Several studies on methane emissions (Kim et al., 1998a; van der Nat and Middelburg, 2000) and $\mathrm{CO}_{2}$ emissions (Zhou et al., 2009) from Phragmites-dominated wetlands have been published. Most of them used the closed chamber method. Despite Phragmites australis being the most abundant wetland species on earth, to date, the eddy covariance (EC) technique has only been used at two study sites: Kim et al. (1998a) performed $\mathrm{CH}_{4}$ flux measurements in a fen in Nebraska, USA, and Zhou et al. (2009) measured $\mathrm{CO}_{2}$ fluxes from a Phragmites wetland in northeast China. To our knowledge, $\mathrm{EC} \mathrm{CO}_{2}$ and $\mathrm{CH}_{4}$ flux data from European Phragmites wetlands does not exist.

To contribute to a better understanding of the role of Phragmites on $\mathrm{CH}_{4}$ and $\mathrm{CO}_{2}$ fluxes, flux measurements were taken in the minerotrophic peatland "Federseemoor," located in southwest Germany. With the EC method, we were able to measure the net ecosystem exchange of $\mathrm{CH}_{4}$ and $\mathrm{CO}_{2}$ in high temporal resolution. This made it possible to detect the influence of the plant-mediated gas transport of Phragmites on the $\mathrm{CH}_{4}$ fluxes and to evaluate the role Phragmites peatland plays in climate change. We recorded diel and seasonal variation of these fluxes, evaluated the impact of environmental variables on the fluxes, and determined the carbon and greenhouse gas budgets of this ecosystem. In this paper, we present the results from a measurement period of 1 year, from March 2013 to February 2014.

\section{Materials and methods}

\subsection{Study site}

The study was conducted in the Federseemoor $\left(48.092^{\circ} \mathrm{N}\right.$, $9.636^{\circ} \mathrm{E}$ ), a peatland with an area of $30 \mathrm{~km}^{2}$ that is located in the Upper Swabia region, southwest Germany. This region is characterized by its moraines and is located on the edge of a high-rainfall zone due to the Alps. Therefore, with yearly precipitation of around $800 \mathrm{~mm}$ and an average temperature of $7.1^{\circ} \mathrm{C}$, the area is wetter and colder than the average for Germany. The Federseemoor developed by natural terrestrialization from a proglacial lake measuring $30 \mathrm{~km}^{2}$ which was formed after the last ice age. The lake diminished to a size of $12 \mathrm{~km}^{2}$ and was surrounded by fen and bog. Between the years of 1787 and 1808, the lake size was further reduced by drainage activities to a size of $1.4 \mathrm{~km}^{2}$. The resulting $11 \mathrm{~km}^{2}$ of reclaimed land was meant for agricultural purposes, but appeared to be unprofitable. Natural vegetation started to develop and today it is a nature conservation area, mainly consisting of fen but also transitional bog and wooded swamp.

The Federsee is completely surrounded by Phragmites vegetation, with a total area of $2.2 \mathrm{~km}^{2}$ and a density of approximately 70 living shoots per $\mathrm{m}^{2}$. To the northeast of the lake, in the middle of the reed, an EC tower was constructed (Fig. 1).

\subsection{Field measurements}

The location of the EC tower was selected so that only reed vegetation was within a $200 \mathrm{~m}$ distance of the tower (the potential footprint). An LI-7700 open-path $\mathrm{CH}_{4}$ gas analyzer (LI-COR Inc., USA), an LI-7200 enclosed $\mathrm{CO}_{2} / \mathrm{H}_{2} \mathrm{O}$ gas analyzer (LI-COR Inc., USA) and a WindMaster Pro ultrasonic anemometer (Gill Instruments Ltd., UK) were installed at a height of $6 \mathrm{~m}$, twice as high as the reed canopy. Molar mixing ratio, mass density of the gases and wind speed in three directions were measured at a frequency of $10 \mathrm{~Hz}$. The LI-7700 is able to detect concentrations of up to $50 \mathrm{ppm}$ $\mathrm{CH}_{4}$ and was calibrated by the manufacturer for the concentration range $0-40 \mathrm{ppm} \mathrm{CH}_{4}$ in June 2012. The LI-7200 was calibrated by the manufacturer up to $740 \mathrm{ppm}$ in July 2012 . The random error of the $\mathrm{CH}_{4}$ flux computed by the EddyPro software (see Sect. 2.3) was around $15 \%$, and $20 \%$ for $\mathrm{CO}_{2}$ flux.

Air temperature and relative humidity (HMP155, Vaisala Inc., Finland) as well as incoming and outgoing shortwave and longwave radiation (CNR4, Kipp \& Zonen BV, the Netherlands) were measured at a height of $6 \mathrm{~m}$. Soil temperature was measured at 5,15 and $30 \mathrm{~cm}$ depths (LI-COR Inc., USA). The groundwater table was continuously measured with a groundwater data logger (Mini-Diver, Eijkelkamp Agrisearch Equipment BV, the Netherlands). Rainfall (TR525USW, Texas Electronics Inc., USA) was measured above the canopy (at a height of $3 \mathrm{~m}$ ). These environmental vari- 


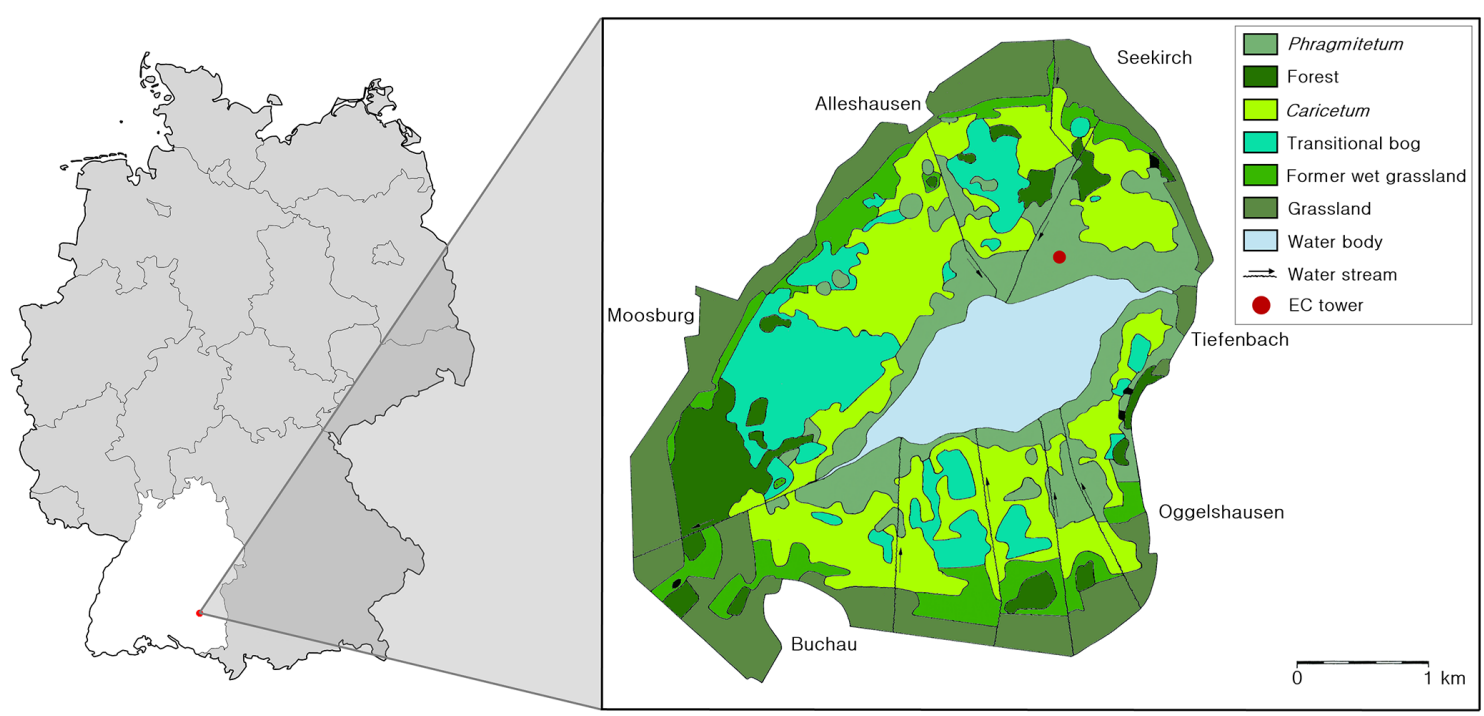

Figure 1. Land cover map of the nature conservation area, Federsee (adapted from Grüttner and Warnke-Grüttner, 1996), located in the Federal State of Baden-Württemberg, Germany. The EC (eddy covariance) tower was built north of the lake, in the center of the largest reed area.

ables were measured every minute, except the water table height which was measured every $30 \mathrm{~min}$. Vegetation height was measured weekly.

\subsection{Flux computation}

Fluxes from 1 March 2013 to 28 February 2014 were calculated with an averaging interval of $30 \mathrm{~min}$ using the software EddyPro version 5.1 (LI-COR Inc., USA). With this software, corrections are applied to average wind directions and gas concentrations and fluxes.

The declination of the angle-of-attack, caused by the shape of the anemometer, was corrected according to Nakai and Shimoyama (2012). To correct the tilt of the anemometer or angle of the mean horizontal wind, the double rotation method was applied (Wilczak et al., 2001). To convert from $\mathrm{CH}_{4}$ mass density to molar concentrations, data were compensated for density fluctuations due to changes in water vapor and temperature (Webb et al., 1980). This does not apply to $\mathrm{CO}_{2} / \mathrm{H}_{2} \mathrm{O}$ gases since the temperature and pressure are constantly maintained in the enclosed-path gas analyzer. Therefore, mixing ratios were used for the flux calculation.

The calculated fluxes were checked for quality by means of the 1-9 flagging system of Foken et al. (2004). Only fluxes with quality flags 1-6 were used for further data processing. Outliers were filtered out by removing fluxes that were more than 4 times the median within a time window of $6 \mathrm{~h}$ and with six or more data points within this time window. Because of the often low turbulent conditions and stable stratification during the night, night fluxes with an average friction velocity $<0.15 \mathrm{~m} \mathrm{~s}^{-1}$ were not considered in the data analysis.

After analyzing the footprint, it appeared that all fluxes were within a $200 \mathrm{~m}$ distance of the tower. The distance of the flux is an output of EddyPro using the method by Kljun et al. (2004), with the criteria that $90 \%$ of the measured gas concentration has its source within that distance. This means that only reed vegetation is within the measured footprint.

\subsection{Gap filling}

Due to technical failures and discarding data because of flux quality criteria, $46 \%$ of the $\mathrm{CH}_{4}$ data and $35 \%$ of the $\mathrm{CO}_{2}$ data were not present. Gaps were filled with the online tool provided by the Max Planck Institute for Biogeochemistry in Jena, Germany (http://www.bgc-jena.mpg.de/ MDIwork/ eddyproc/). This tool uses the look-up table method described by Falge et al. (2001) and Reichstein et al. (2005). This method was developed to fill $\mathrm{CO}_{2}$ flux gaps. It uses the correlation of $\mathrm{CO}_{2}$ fluxes with meteorological variables such as global radiation, ambient temperature and vapor pressure deficit.

To date, there is no established gap filling method for $\mathrm{CH}_{4}$. Nevertheless, we found clear correlations between $\mathrm{CH}_{4}$ fluxes and global radiation, temperature and relative humidity in our data. Therefore, we used the same gap filling method for $\mathrm{CH}_{4}$ as for $\mathrm{CO}_{2}$.

In the case of power or data logger failure, meteorological data were taken from a meteorological station run by the Federal State of Baden-Württemberg (LUBW) at a $2.2 \mathrm{~km}$ distance from the EC station.

Even with these data, the online tool still lacked sufficient data to properly fill a 2-month data gap that was caused by insufficient solar power within the time period 24 November 2013-30 January 2014. This was due to the maximum time window (14 days) that the tool uses. Therefore, a look-up table was made manually to fill this data gap. Global radiation 

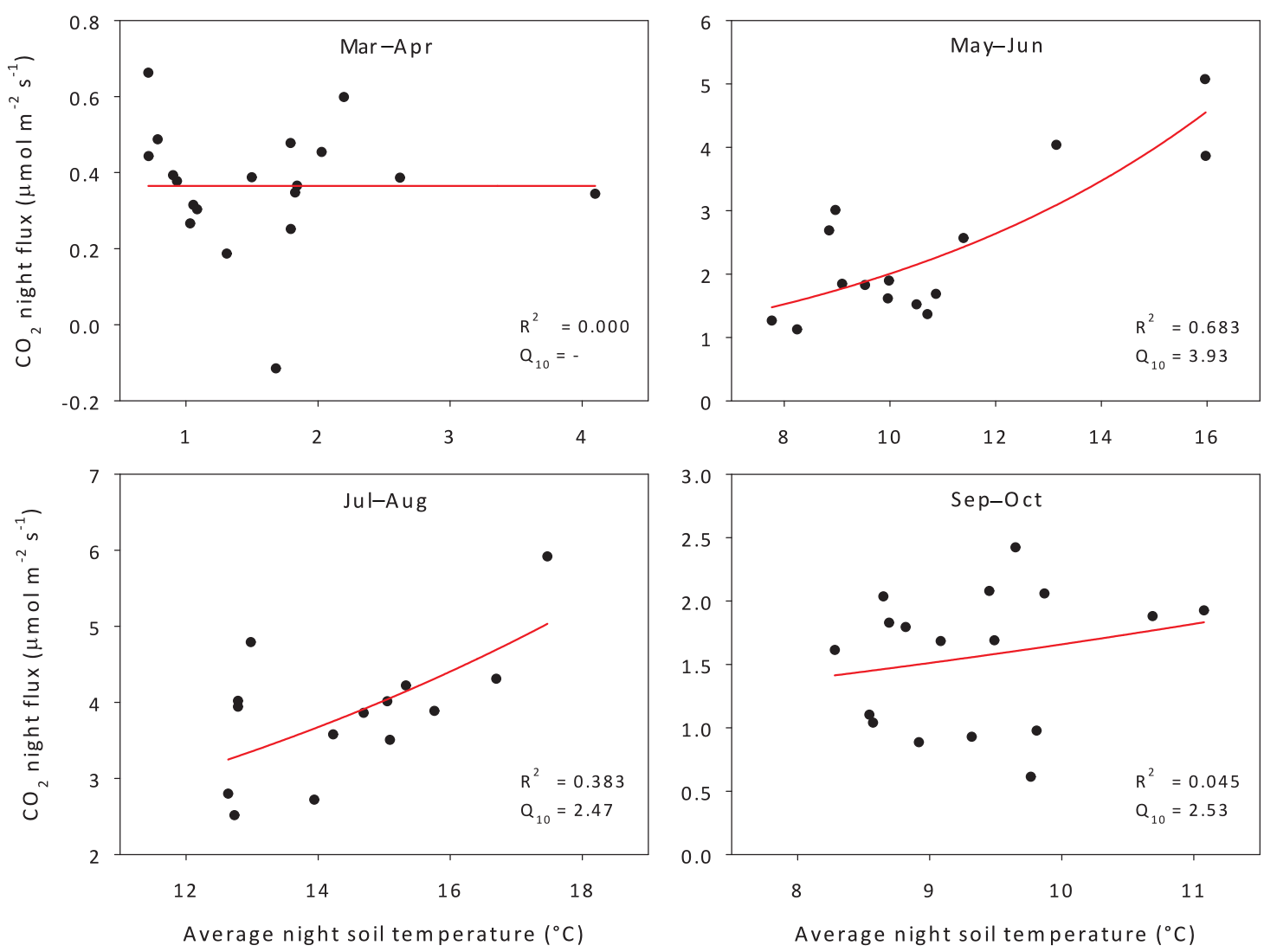

Figure 2. Average $\mathrm{CO}_{2}$ night fluxes for every 2-month period during the growing season plotted against average night soil temperature (black dots) with the regression model outcome (red lines).

classes with an interval of $100 \mathrm{~W} \mathrm{~m}^{-2}$ (from $0-800 \mathrm{~W} \mathrm{~m}^{-2}$ ) and ambient temperature classes with an interval of $4{ }^{\circ} \mathrm{C}$ (from $-10-18^{\circ} \mathrm{C}$ ) were created. For every combined class of temperature and global radiation, the average flux was used from the available data from November and February with the same class. Gaps in the look-up table were filled by linear interpolation. To estimate how reliable these gap-filled data were, an artificial gap was created for the month of May and was filled based on a look-up table created with data from April. The difference between observed and estimated data was on average $+30 \%$. Therefore, data from the filled gap of December-January are only used for the annual carbon budget estimation, but not for statistical analyses.

\subsection{Separating net ecosystem exchange}

The $\mathrm{CO}_{2}$ fluxes measured with EC are the net ecosystem exchange (NEE). By definition, this is the gross ecosystem production (GEP) minus the ecosystem respiration $\left(R_{\text {eco }}\right)$. Separating $R_{\text {eco }}$ and GEP from NEE is done by using a simplified form of the regression model by Lloyd and Taylor (1994; Eq. 1) which describes the relation between respiration and temperature. The $Q_{10}$ value was derived by a regression of the average $\mathrm{CO}_{2}$ night flux $\left(R_{\text {eco }}\right)$ on the average night soil temperature $\left(T\right.$; in $\left.{ }^{\circ} \mathrm{C}\right)$ for every 2 months (more or less the duration of the different plant development stages) over the vegetation period (March-October):

$R_{\mathrm{eco}}=R_{0} \times Q_{10}^{T / 10}$

$R_{0}$ is the respiration when $T$ is equal to 0 . Only average night fluxes with six or more data points were considered and night is determined as the period where global radiation $<10 \mathrm{~W} \mathrm{~m}^{-2}$. The $Q_{10}$ values of the ecosystem respiration $\left(R_{\text {eco }}\right)$ obtained (between 1.53 and 3.93; see Fig. 2) were used to calculate the $R_{\text {eco }}$ for every half hour during the day within the vegetation period. This was done by using the average $\mathrm{CO}_{2}$ night flux as the reference respiration $\left(R_{\mathrm{ref}}\right)$ and the corresponding average night temperature as reference temperature $\left(T_{\text {ref }}\right)$. The difference between $T_{\text {ref }}$ and the daytime temperature was used to calculate the difference between $R_{\text {ref }}$ during daytime $R_{\text {eco }}$. The GEP was then calculated by subtracting $R_{\text {eco }}$ from NEE for every half hour during the day. The only period in which we found no dependency between $\mathrm{CO}_{2}$ night fluxes and soil temperature was March-April. This is very likely to be due to the low soil temperature during this period (mostly below $4{ }^{\circ} \mathrm{C}$ ). For these 2 


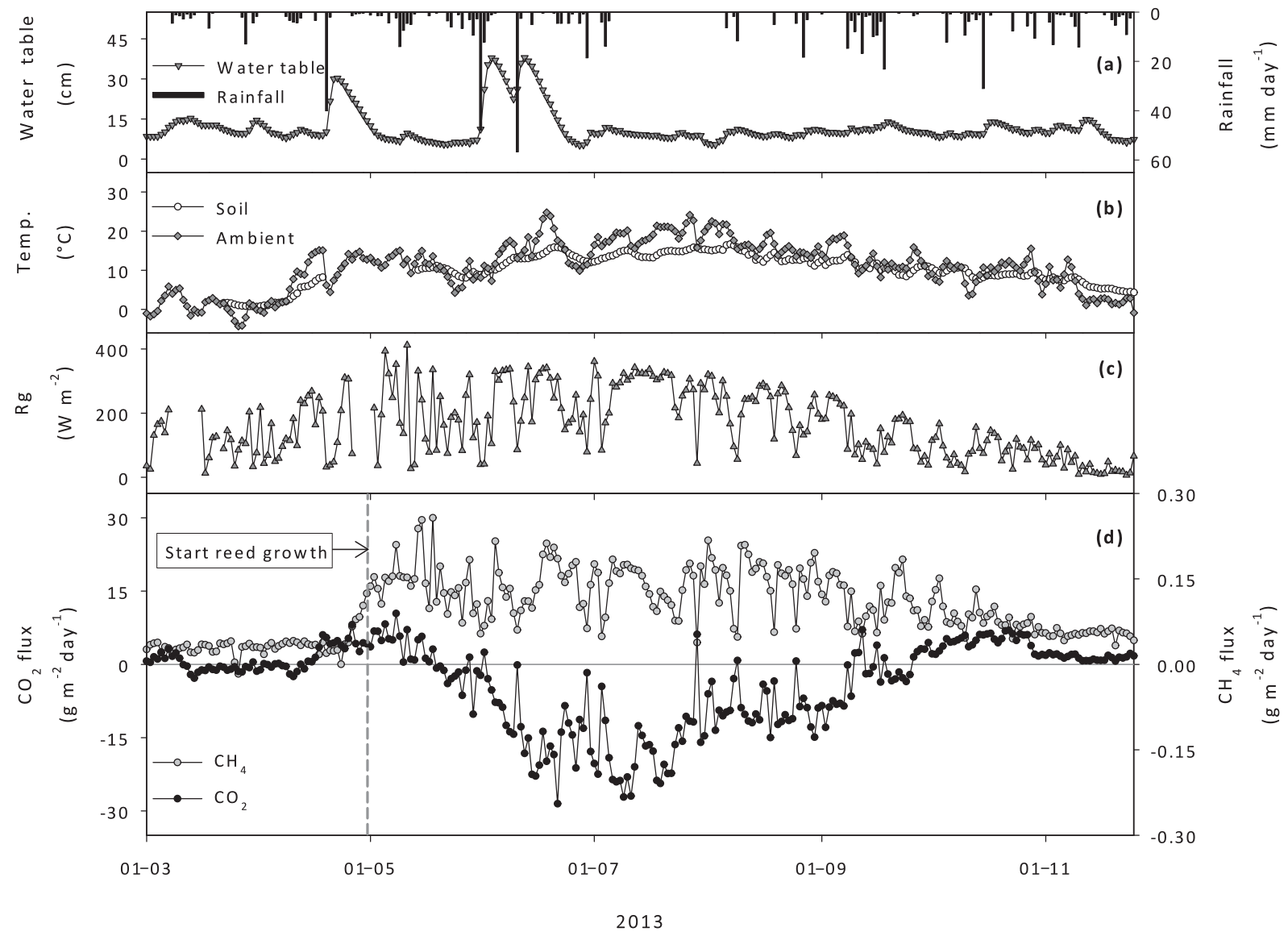

Figure 3. (a) Daily averages of water table and rainfall, (b) soil and ambient temperature, (c) global radiation $(\mathrm{Rg})$ and $(\mathbf{d}) \mathrm{CO}_{2}$ and $\mathrm{CH}_{4}$ fluxes in the period 1 March-25 November 2013.

months, daytime respiration was estimated by taking the average night $\mathrm{CO}_{2}$ flux from that same day.

\subsection{Statistics}

Biserial (Pearson's) and partial correlation coefficients were calculated to explore the relationship between measured gas fluxes and environmental factors. For this we used the data at half-hourly resolution. Because the samples are autocorrelated in time and hence not independent, no confidence intervals were inferred and correlation coefficients were interpreted solely in a descriptive manner.

The impact of environmental factors on the gas fluxes was analyzed by polynomial regression models, making it possible to also model nonlinear relationships between environmental factors and gas fluxes. Because of the autocorrelative structure of the data, the regression models were made with the ARIMA (autoregressive integrated moving average) Box-Jenkins modeling approach. To achieve stationarity (constant expectation and variance) all data (gas fluxes and potential regressor variables) were differenced prior to the analysis. For the ARIMA analysis we used the daily- averaged data measured in the vegetation period from 14 May to 31 October.

All statistical analyses were performed with the software PASW Statistics for Windows, Version 18.0 (SPSS Inc., released in 2009).

\section{Results}

\subsection{Seasonal pattern in gas fluxes and environmental variables}

The daily averages of $\mathrm{CO}_{2}$ and $\mathrm{CH}_{4}$ fluxes are presented in Fig. 3 together with the most important environmental variables. Only data until 25 November 2013 are shown because of the large amount of missing data after this date. The Northern Hemisphere's seasonal pattern is clearly visible in temperature and global radiation. These variables show the highest values in July, with average air and soil temperatures of 19 and $14{ }^{\circ} \mathrm{C}$, respectively, and daily-averaged global radiation of $278 \mathrm{~W} \mathrm{~m}^{-2}$. During the whole year, the water table never dropped below the soil surface, which means that the soil was water-saturated for the whole time. 
The increase of temperature and global radiation at the beginning of the season initiated reed growth, starting by 30 April. From May, the reed plants assimilated $\mathrm{CO}_{2}$ and daily $\mathrm{CO}_{2}$ fluxes became clearly negative. At the same time, $\mathrm{CH}_{4}$ fluxes rapidly increased. With green reed present, both $\mathrm{CO}_{2}$ and $\mathrm{CH}_{4}$ daily fluxes mainly follow global radiation (see Sect. 3.3) but in an inverse manner. This suggests a high influence of the vegetation on both fluxes. The highest $\mathrm{CO}_{2}$ fluxes were measured in July, the month with the highest temperatures and maximum reed height $(260 \mathrm{~cm})$. In July, the average flux was $-17.5 \mathrm{~g} \mathrm{CO}_{2} \mathrm{~m}^{-2} \mathrm{~d}^{-1}$. The highest fluxes of $\mathrm{CH}_{4}$ were measured in August, with an average of $0.151 \mathrm{~g} \mathrm{CH}_{4} \mathrm{~m}^{-2} \mathrm{~d}^{-1}$. From early October, when the reed entered the senescence stage, fluxes became smaller $\left(\mathrm{CO}_{2}\right.$ positive) and on average there was no longer any uptake of $\mathrm{CO}_{2}$. The lowest fluxes were measured in winter (November-February, data not shown), with an average release of $2.72 \mathrm{~g} \mathrm{CO}_{2} \mathrm{~m}^{-2} \mathrm{~d}^{-1}$ and $0.044 \mathrm{~g} \mathrm{CH}_{4} \mathrm{~m}^{-2} \mathrm{~d}^{-1}$.

\subsection{Diurnal pattern}

To see how diurnal cycles of both $\mathrm{CO}_{2}$ and $\mathrm{CH}_{4}$ fluxes change over the season, the monthly-averaged diel fluxes of both gases are presented in hourly resolution (Fig. 4). $\mathrm{CO}_{2}$ shows a weak diurnal pattern in the months of March and April, while there is no clear pattern visible for $\mathrm{CH}_{4}$. From May onwards, when new reed was present, a distinct diurnal pattern was established for both gases, with the highest negative fluxes for $\mathrm{CO}_{2}$ and highest positive fluxes for $\mathrm{CH}_{4}$ between 10:00 and 13:00. Over the whole growing season, the daily maximum for $\mathrm{CH}_{4}$ and $\mathrm{CO}_{2}$ flux was on average 15 and $30 \mathrm{~min}$, respectively, earlier than the radiation maximum. The highest midday-night difference for $\mathrm{CH}_{4}$ was observed in August with, on average, a midday flux of 15.7 and a night flux of $1.41 \mathrm{mg} \mathrm{CH}_{4} \mathrm{~m}^{-2} \mathrm{~h}^{-1}$. These values differ by a factor of 11. The highest uptake of $\mathrm{CO}_{2}$ that occurred around noon was in July $\left(2.36 \mathrm{~g} \mathrm{CO}_{2} \mathrm{~m}^{-2} \mathrm{~h}^{-1}\right)$. Also in this month the highest night flux was observed, on average a release of $0.629 \mathrm{~g} \mathrm{CO}_{2} \mathrm{~m}^{-2} \mathrm{~h}^{-1}$.

The diurnal pattern of $\mathrm{CO}_{2}$ disappeared in October. From November onwards, only positive fluxes were measured. The diurnal pattern of $\mathrm{CH}_{4}$ continued for 1 month longer and almost vanished in November.

\subsection{Factors affecting the fluxes during growing season}

Figure 5 shows the results of the partial correlation analysis of the half-hourly data for the growing period (MayOctober). $\mathrm{CH}_{4}$ flux shows the highest correlation with global radiation, followed by relative humidity and air temperature. The biserial correlation between $\mathrm{CH}_{4}$ fluxes and global radiation changes very little, no matter which other factor is partialed out. This suggests that global radiation is the most important factor influencing $\mathrm{CH}_{4}$ fluxes. The high biserial correlation of $\mathrm{CH}_{4}$ flux with relative humidity and air tem- perature decreases considerably when global radiation is partialed out. This means that the correlations of relative humidity and air temperature with the $\mathrm{CH}_{4}$ flux are based, to a large extent, on their correlation with global radiation. It is notable that the correlation of the $\mathrm{CH}_{4}$ flux with soil temperature is small. The correlation even becomes negative when air temperature is partialed out. During the winter period, results differ: $\mathrm{CH}_{4}$ flux correlates most with soil temperature ( $r=0.371)$, followed by water table height $(r=0.222$; data not shown).

The correlation table for $\mathrm{CO}_{2}$ fluxes shows the same pattern but is the inverse of $\mathrm{CH}_{4}$, except that the correlations with air and soil temperature are higher than those of $\mathrm{CH}_{4}$.

The impact of environmental factors on the daily fluxes of $\mathrm{CH}_{4}$ and $\mathrm{CO}_{2}$ fluxes was evaluated by regression analysis in the framework of the ARIMA approach. An ARIMA $(0,1,1)$ model was found to be suited to model the flux time series of both $\mathrm{CH}_{4}$ and $\mathrm{CO}_{2}$ (Table 1). Global radiation turned out to be the only regressor with a statistically significant impact $(P<0.05)$ on the $\mathrm{CH}_{4}$ fluxes, and global radiation and soil temperature on the $\mathrm{CO}_{2}$ fluxes. A second order polynomial model describes the relation between global radiation and $\mathrm{CH}_{4}$ flux as well as $\mathrm{CO}_{2}$ flux best. In the $\mathrm{CO}_{2}$ model, the addition of soil temperature as a linear regression term gave the best model results. Other environmental factors, such as relative humidity and air temperature, also covary with the fluxes, but their possible impact on the fluxes cannot be determined because it is screened due to their correlation with global radiation and soil temperature. After differencing the data, the resulting models for $\mathrm{CH}_{4}$ and $\mathrm{CO}_{2}$, are given by Eqs. (2) and (3):

$$
\begin{aligned}
\Delta \mathrm{CH}_{4} \text { flux }_{t} & =\beta_{1} \times \Delta \mathrm{Rg}_{t}+\beta_{2} \times \Delta \mathrm{Rg}_{t}^{2}+e_{t}-\theta e_{t-1} \\
\Delta \mathrm{CO}_{2} \text { flux }_{t} & =\beta_{1} \times \Delta T_{\text {soil }_{t}}+\beta_{2} \times \Delta \mathrm{Rg}_{t}+\beta_{3} \\
& \times \Delta \mathrm{Rg}_{t}^{2}+e_{t}-\theta \times e_{t-1},
\end{aligned}
$$

where $\Delta$ is the differencing operator (e.g., $\Delta \mathrm{CH}_{4, t}=\mathrm{CH}_{4, t}-$ $\left.\mathrm{CH}_{4, t-1}\right), \beta$ a regression coefficient, $\theta$ the weight of the moving average (MA) term and $e_{t}$ the residual error term that is assumed to be independently normally distributed (white noise). The coefficient of determination $\left(R^{2}\right)$ of the $\mathrm{CH}_{4}$ model with differenced data is 0.79 . Without the error term $\left(e_{t}-\theta \mathrm{e}_{t-1}\right), R^{2}$ is 0.76 . In the case of $\mathrm{CO}_{2}$, the model performance is much lower $\left(R^{2}=0.47\right.$ with error term and $R^{2}=0.26$ without error term). For comparison, when only the regression part of the model is run with non-differenced data $\left(\mathrm{CH}_{4}\right.$ flux $_{t}=$ constant $\left.+\beta \times \mathrm{Rg}_{t}\right)$ the coefficient of determination became 0.57 . In the case of $\mathrm{CO}_{2}$, the respective value is 0.61 . Figure 6 gives an impression of the model performance over time, again without making use of the error terms for the predictions.

The high correlation of global radiation with the $\mathrm{CH}_{4}$ fluxes suggests an influence of the plants on the fluxes. The internal gas transport mechanism of Phragmites (HIC) is expected to be regulated by the stomata (influenced by radia- 


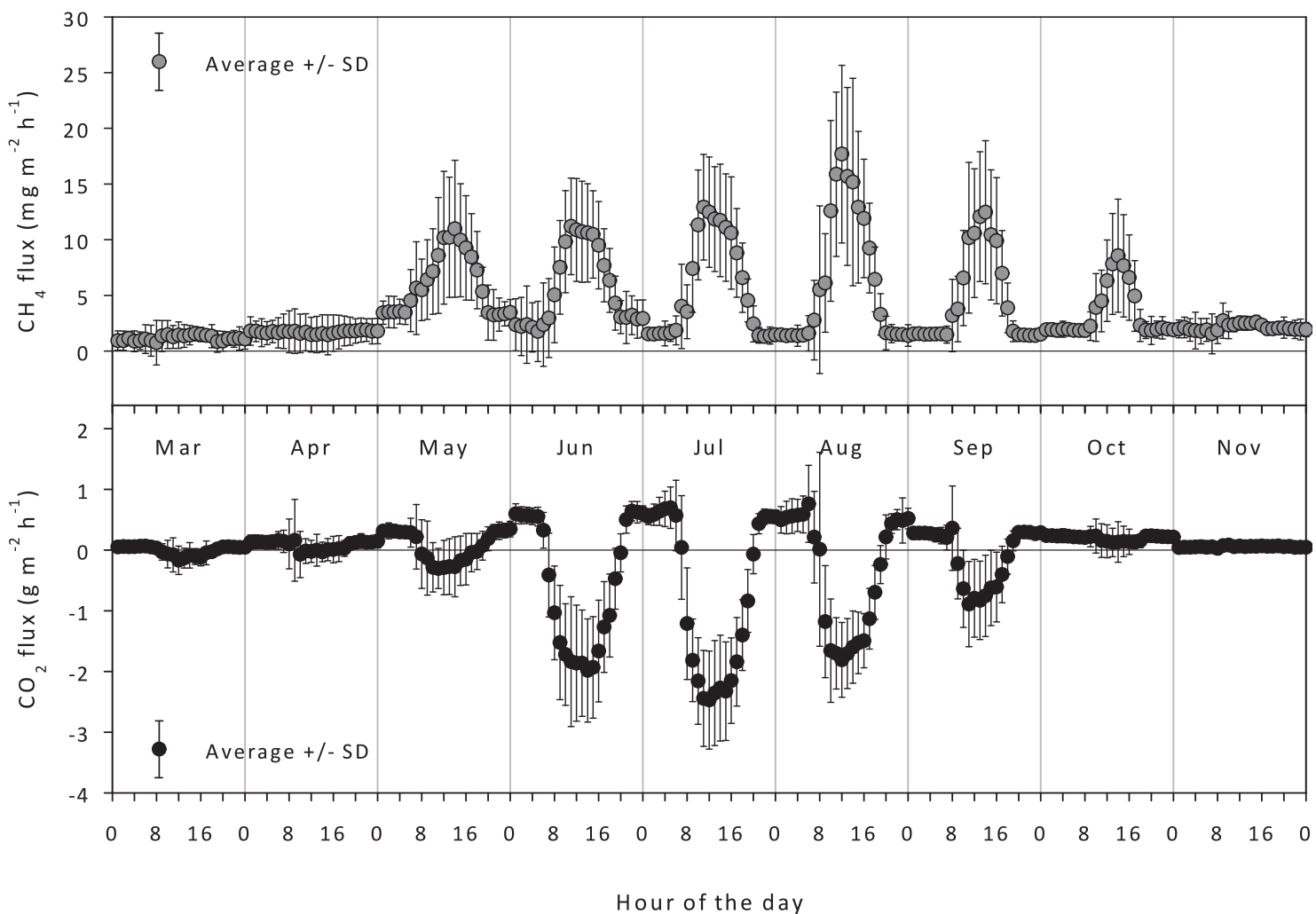

Figure 4. Diurnal cycles of $\mathrm{CH}_{4}$ (above) and $\mathrm{CO}_{2}$ (below) from March to November 2013. Each point represents the flux averaged over a specific hour of the day averaged over 1 month. Error bars denote standard deviations.

Table 1. Model parameters and statistics of the $\mathrm{CO}_{2}$ and $\mathrm{CH}_{4}$ ARIMA $(0,1,1)$ models.

\begin{tabular}{lrrr|rrr}
\hline & \multicolumn{2}{c|}{$\mathrm{CH}_{4}$ flux $\left(\mathrm{g} \mathrm{m}^{-2} \mathrm{day}^{-1}\right)$} & \multicolumn{2}{c}{$\mathrm{CO}_{2}$ flux $\left(\mathrm{g} \mathrm{m}^{-2} \mathrm{day}^{-1}\right)$} \\
\cline { 2 - 7 } Model variable & coefficient $(\beta, \theta)$ & $t$ & $P$ value & coefficient $(\beta, \theta)$ & $t$ & $P$ value \\
\hline $\mathrm{Rg}\left(\mathrm{W} \mathrm{m}^{-2}\right)$ & $7.15 .10^{-4}$ & 8.83 & $<0.000$ & -0.0859 & -5.42 & $<0.000$ \\
$\mathrm{Rg}^{2}\left(\mathrm{~W} \mathrm{~m}^{-2}\right)$ & $-6.07 .10^{-7}$ & -2.94 & 0.004 & $1.36 .10^{-4}$ & 3.41 & 0.001 \\
$T_{\text {soil }\left({ }^{\circ} \mathrm{C}\right)}$ & & & & -0.950 & -2.56 & 0.011 \\
MA lag 1 & 0.388 & 5.41 & $<0.000$ & 0.671 & 11.2 & $<0.000$ \\
\hline
\end{tabular}

tion) and humidity differences between the atmosphere and plant culm. Because relative humidity highly correlates with global radiation, we selected small intervals of global radiation within a temperature range between $10-20^{\circ} \mathrm{C}$ and evaluated the correlation between relative humidity and $\mathrm{CH}_{4}$ fluxes within these intervals (see Fig. 7). Only with low radiation $\left(3-10 \mathrm{~W} \mathrm{~m}^{-2}\right)$ is there a clear negative correlation. With higher radiation intensities $\left(293-300\right.$ and $593-600 \mathrm{~W} \mathrm{~m}^{-2}$ ) the correlation disappears.

\subsection{Carbon and greenhouse gas balance}

Figure 8a shows the monthly cumulative fluxes of $R_{\mathrm{eco}}$, GEP and $\mathrm{CH}_{4}$. The highest fluxes for $R_{\text {eco }}$ and GEP were measured in July and for $\mathrm{CH}_{4}$ in August $\left(3.5 \mathrm{~g} \mathrm{C} \mathrm{m}^{-2}\right)$. The con- tribution of $\mathrm{CH}_{4}$, however, to the overall carbon flux is minor. From June to September, the contribution of GEP was higher than that of $R_{\text {eco }}$ plus $\mathrm{CH}_{4}$, resulting in a net carbon uptake during these months. This uptake more than compensates the net release of carbon in the other months. The net yearly $\mathrm{CO}_{2}$ uptake was $894 \mathrm{~g} \mathrm{~m}^{-2} \mathrm{a}^{-1}$ and the $\mathrm{CH}_{4}$ emission was $30 \mathrm{~g} \mathrm{~m}^{-2} \mathrm{a}^{-1}$ (see Table 2). This leads to a net annual uptake of carbon of $221 \mathrm{~g} \mathrm{C} \mathrm{m}^{-2}$ by the reed ecosystem, corresponding to $26 \%$ of the GEP. $\mathrm{CH}_{4}$ plays a minor role in the carbon balance, but with a global warming potential (GWP) of 28 (GWP $_{100}$, IPCC 2013), it heavily affects the greenhouse gas balance (see Fig. 8b). With an uptake of $52 \mathrm{~g} \mathrm{CO}_{2}$ eq. $\mathrm{m}^{-2} \mathrm{yr}^{-1}$, the ecosystem is a minor greenhouse gas sink (see Table 2). 
Partial-correlation table

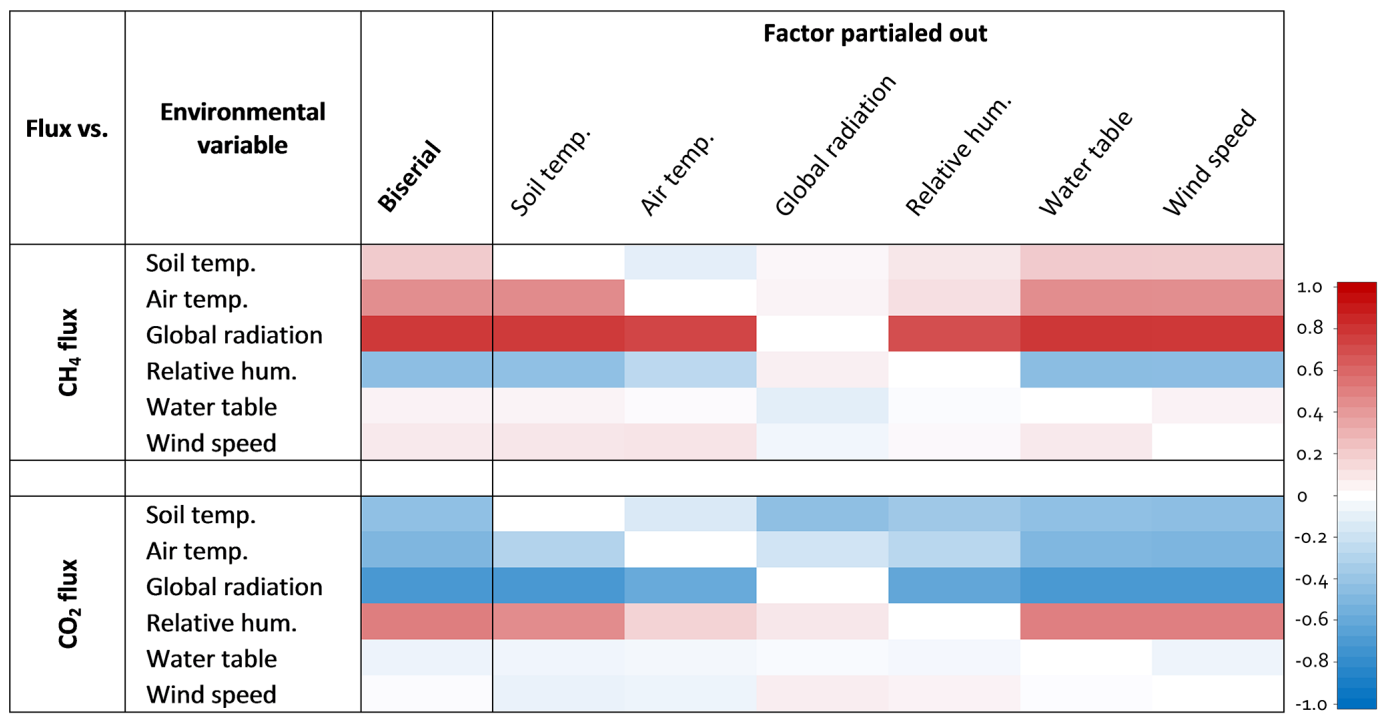

Figure 5. Biserial and partial correlations between $\mathrm{CH}_{4}$ flux (above) or $\mathrm{CO}_{2}$ flux (below) and environmental variables within the growing season (May-October). Each variable (soil temperature, air temperature, global radiation, relative humidity, water table height and wind speed) is partialed out and the corresponding correlations with the other variables are shown in the same column. The darker the cells the higher the correlation coefficient, with the red colors for positive correlations and blue colors for negative correlations.
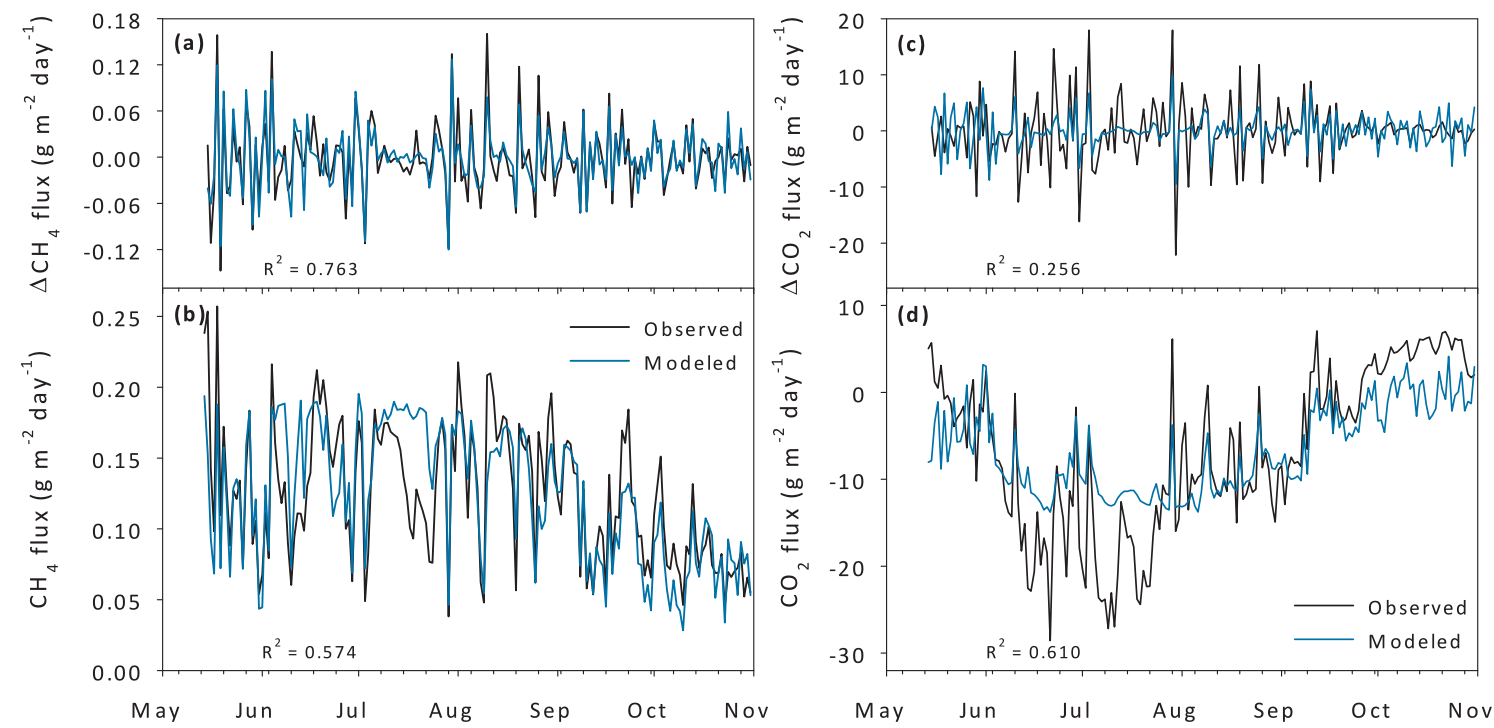

Figure 6. Observed and modeled daily fluxes of (a) differenced data for $\mathrm{CH}_{4}$, (b) original data for $\mathrm{CH}_{4}$, (c) differenced data for $\mathrm{CO}_{2}$ and (d) original data for $\mathrm{CO}_{2}$. The modeled data are created with an ARIMA $(0,1,1)$ model, with $\mathrm{Rg}$ as the explaining variable for $\mathrm{CH}_{4}$, and $\mathrm{Rg}$ and $T_{\text {soil }}$ for $\mathrm{CO}_{2}$. The error terms with the autoregressive part for the modeled data are not included in these graphs or in the coefficients of determination $\left(R^{2}\right)$.

\section{Discussion}

\section{1 $\mathrm{CH}_{4}$ fluxes and plant-mediated gas transport}

In the period that the above-ground plant parts were alive and green, we observed a distinct diurnal pattern in the $\mathrm{CH}_{4}$ fluxes. The highest emission was observed around noon and the lowest during the night. Similar diurnal $\mathrm{CH}_{4}$ flux patterns from Phragmites-dominated wetlands were reported by Kim et al. (1998b), who used the EC method and by van der Nat et al. (1998) and Grünfeld and Brix (1999), who performed studies with closed chambers. The observed pattern can be explained by the gas transport mechanism within the culm of the Phragmites plants. This mechanism is described by 


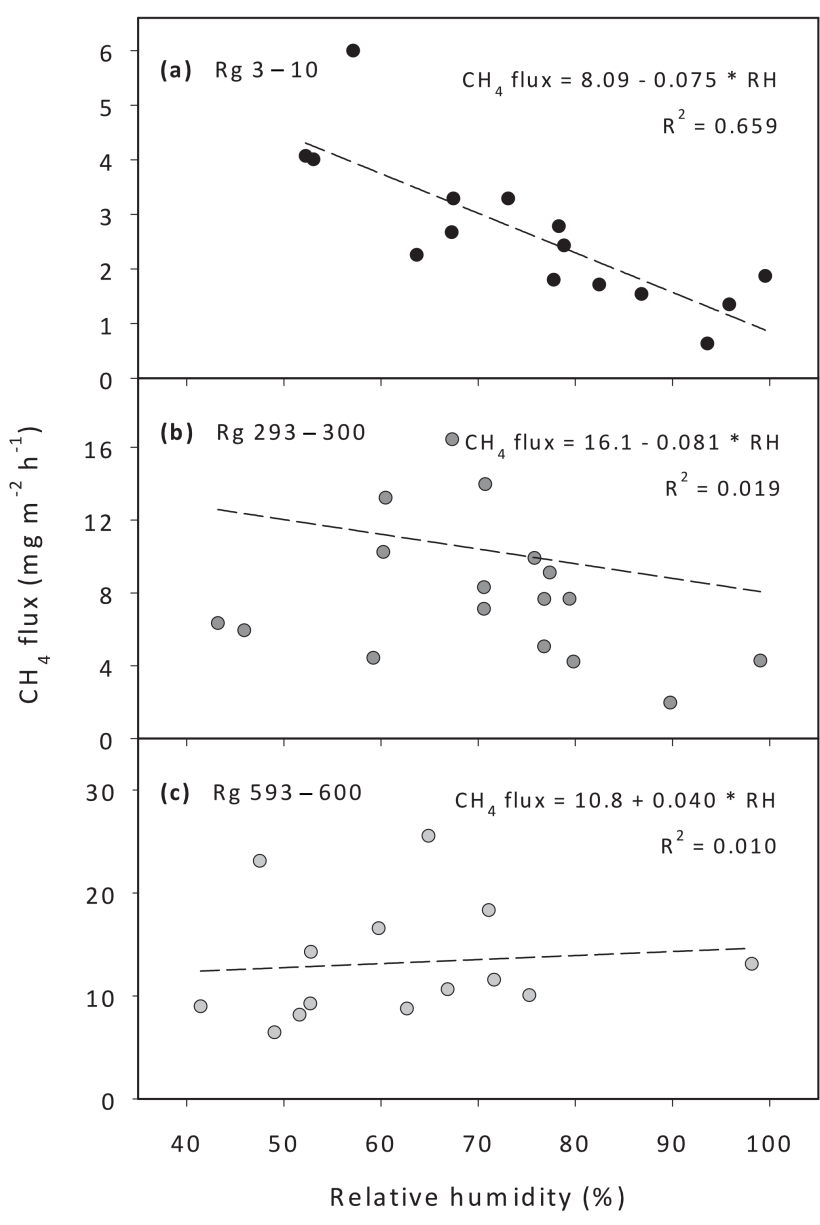

Figure 7. $\mathrm{CH}_{4}$ flux plotted against relative humidity (RH). Data are selected by global radiation $(\mathrm{Rg})$ in the range (a) 3-10, (b) 293 300 and (c) $593-600 \mathrm{~W} \mathrm{~m}^{-2}$. Only data with a corresponding air temperature between $10-20{ }^{\circ} \mathrm{C}$ are displayed.

Table 2. Annual integrated flux, carbon balance and greenhouse gas (GHG) balance for $\mathrm{CH}_{4}, \mathrm{CO}_{2}$ and the sum of both gases for carbon and GHG balance.

\begin{tabular}{|c|c|c|c|}
\hline & $\begin{array}{r}\text { Integrated flux } \\
\qquad\left(\mathrm{g} \mathrm{m}^{-2}\right)\end{array}$ & $\begin{array}{r}\text { Carbon balance } \\
\qquad\left(\mathrm{g} \mathrm{C} \mathrm{m}^{-2}\right)\end{array}$ & $\begin{array}{r}\text { GHG balance } \\
\left(\mathrm{g} \mathrm{CO}_{2} \text { eq. } \mathrm{m}^{-2}\right)\end{array}$ \\
\hline $\mathrm{CH}_{4}$ & 30 & 23 & 842 \\
\hline $\mathrm{CO}_{2}$ & -894 & -244 & -894 \\
\hline sum & & -221 & -52 \\
\hline
\end{tabular}

Armstrong and Armstrong $(1990,1991)$ and Armstrong et al. (1992, 1996a, b) as HIC. According to these publications, a convective flow is generated due to an elevated air pressure in the plant stem caused by a humidity gradient (regulated by the stomata) between the inner part of the leaf sheaths and the atmosphere. The higher pressure creates an air flow through the entire stem and rhizomes that is vented via old (broken) stems. This process starts after sunrise, is at its op-

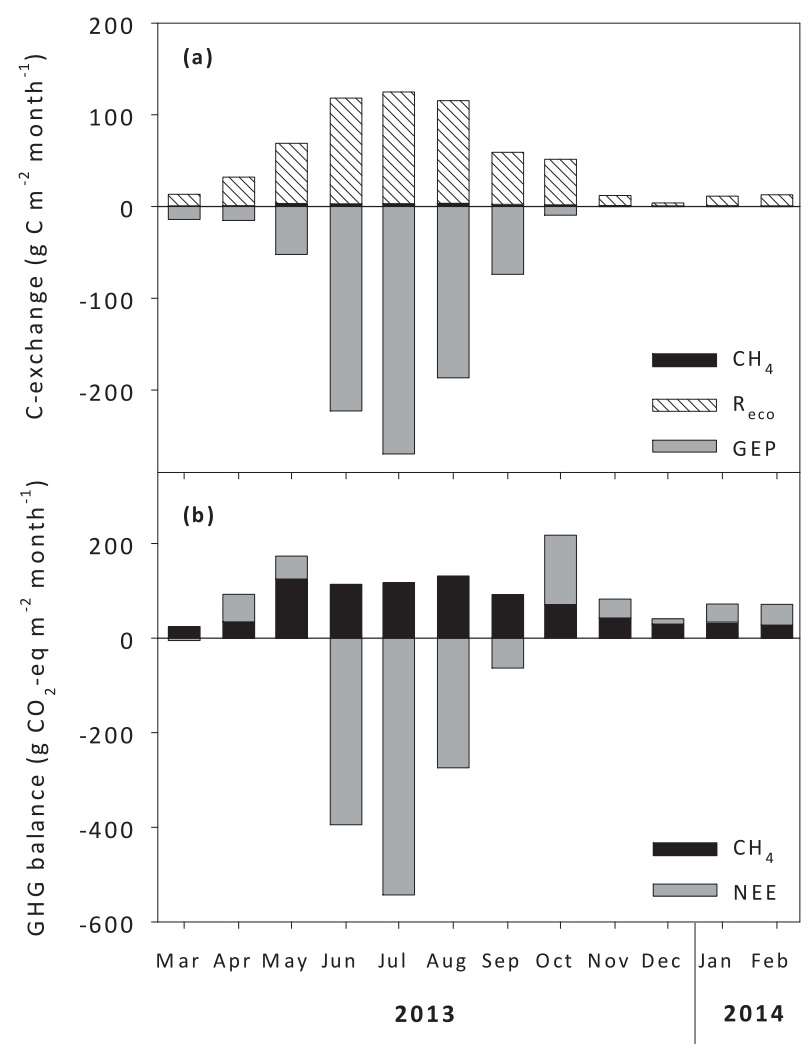

Figure 8. (a) Monthly accumulated carbon fluxes from $\mathrm{CH}_{4}$ and $\mathrm{CO}_{2}$ divided between ecosystem respiration $\left(R_{\mathrm{eco}}\right)$ and gross ecosystem production (GEP). (b) Carbon fluxes in $\mathrm{CO}_{2}$ equivalence from $\mathrm{CO}_{2}$ (net ecosystem exchange, $\mathrm{NEE}$ ) and $\mathrm{CH}_{4}$, where $\mathrm{CH}_{4}$ fluxes are multiplied by a global warming potential $\left(\mathrm{GWP}_{100}\right)$ of factor 28 (IPCC, 2013).

timum in the early afternoon and decreases until sunset (Brix et al., 2001). During the night, when stomata are closed, gas transport in the stems solely takes place via diffusion. Arkebauer et al. (2001) measured air pressure in stems of Phragmites in the field and observed the same diurnal pattern as we found in the $\mathrm{CH}_{4}$ flux data. Brix et al. (1992a) found the same pattern with four different wetland plants (including Phragmites). They both showed that stem pressure (and convective flow in Brix et al., 1992b) correlates with radiation, air temperature and relative humidity. These correlations with HIC were also found in lab experiments (Armstrong and Armstrong, 1991). We found only a strong correlation of $\mathrm{CH}_{4}$ fluxes with global radiation during the growing season. The correlations we found with air temperature and relative humidity can also be explained by the dependency of these variables on global radiation. It is unexpected that the correlation with relative humidity is not prominent, since this is the driving factor behind HIC. Armstrong and Armstrong (1991) found that convective flow and relative humidity were negatively correlated with a convective flow close 
to 0 and a relative humidity of $100 \%$. This lab experiment, however, was carried out with a very low, constant light intensity $\left(4.4 \mathrm{~W} \mathrm{~m}^{-2}\right)$. Sunlight intensity can be more than 200 times higher. When we selected our measured data within the same light intensity range ( $\operatorname{Rg} 3-10 \mathrm{~W} \mathrm{~m}^{-2}$ ), we found exactly the same negative correlation between $\mathrm{CH}_{4}$ fluxes and relative humidity as Armstrong and Armstrong (1991). With higher light intensities, however, the correlation vanished. In that same study and in another study (Armstrong and Armstrong, 1990) a correlation was found between photosynthetically active radiation (PAR) and air flow within the plant stem. Radiation can create a temperature difference between the stem and air, this increases the pressure inside the stem compared to the air pressure, which can also create a convective flow. This phenomenon is called thermal transpiration, but in Phragmites the contribution is believed to be small (Armstrong and Armstrong, 1991; Armstrong et al., 1996a). It also appears that convective flow increases much more with PAR than with infrared radiation (Armstrong and Armstrong, 1990), which speaks against the thermal transpiration hypothesis. The strong correlation between global radiation and $\mathrm{CH}_{4}$ flux that we observed and the fact that the dominant role of radiation was confirmed in the ARIMA analysis suggests that a mechanism related to stomatal control or photosynthesis might play a role in the creation of a convective flow. But the question still remains how? Based on our data we cannot give an answer to this question.

We found the highest midday-night difference was in the month of August when the reed was fully grown. On average, midday emissions during this month were 11 times higher than at night. This is more than 2 times higher than the highest difference Kim et al. (1998b) found in a Phragmitesdominated marsh in Nebraska. In a lab experiment by Grünfeld and Brix (1999), midday and night fluxes differed by a factor 2.5, which is also much lower than in our study. The reason for this deviation might be the density of the Phragmites plants for which convective flow is expected to be directly proportional. At our site, the density of living green Phragmites plants is almost twice as high $\left(68 \mathrm{~m}^{-2}\right)$ as in the prairie marsh in Nebraska (Kim et al., 1998b).

The question remains whether the overall $\mathrm{CH}_{4}$ flux increases or decreases due to the presence of living, green reed. In our data, we found a very clear increase in the daily $\mathrm{CH}_{4}$ flux after the beginning of reed growth. Soil temperature also increased in the month of May, but not in proportion to the $\mathrm{CH}_{4}$ flux. An increase of the $\mathrm{CH}_{4}$ flux due to the presence of living reed would be in contradiction to an experiment performed by Grünfeld and Brix (1999). They found a decrease in the $\mathrm{CH}_{4}$ emissions of $34 \%$ with the addition of Phragmites to a submerged organic soil. Their explanation is that methanogenesis is reduced and $\mathrm{CH}_{4}$ oxidation increased because of the transport of oxygen by Phragmites into the rhizosphere. In a soil without reed, the gas transport would be dominated by ebullition. Transport by ebullition is faster than internal plant transport, so that less of the produced methane is oxidized. Hendriks et al. (2010) found the opposite in a field study with water table differences and vascular wetland plants. A high water table and vascular plants showed higher methane emission than the same soil and water table without vascular plants. Kankaala et al. (2004) found a higher contribution of ebullition to the $\mathrm{CH}_{4}$ flux in a less dense Phragmites shore zone ( 24 shoots $\mathrm{m}^{-2}$ ) than in a dense area (78 shoots $\mathrm{m}^{-2}$ ). The less dense Phragmites zone showed 3 -fold higher $\mathrm{CH}_{4}$ emissions than the denser area. Koch et al. (2014) also found a negative correlation of methane fluxes with Phragmites abundance. Given this negative correlation, the high density of 68 shoots $\mathrm{m}^{-2}$ at our site would suggest that total $\mathrm{CH}_{4}$ flux would be lower compared to wetlands with lower densities. Our observed yearly $\mathrm{CH}_{4}$ flux of $30 \mathrm{~g} \mathrm{~m}^{-2} \mathrm{a}^{-1}$ is in the same range as Kankaala et al. (2004), who found similar dense reed vegetation $\left(20-50 \mathrm{~g} \mathrm{~m}^{-2} \mathrm{a}^{-1}\right)$ and indeed almost 3 times lower than the flux measured by Kim et al. (1998b) in a reed density of only 35 shoots $\mathrm{m}^{-2}$. So even though our site has a relative low net $\mathrm{CH}_{4}$ flux, it is likely that plant-mediated gas transport during the growing season could lead to higher $\mathrm{CH}_{4}$ emissions compared to winter, if in both seasons the ebullition is reduced due to the plant density.

\subsection{Effect of other environmental factors on $\mathrm{CH}_{4}$}

Another influence of the plants on the $\mathrm{CH}_{4}$ fluxes could be the release of root exudates, which is closely linked to photosynthesis. Root exudates lead to an increase in substrate availability in the form of easily decomposable organic compounds, which can be used by methanogens to produce $\mathrm{CH}_{4}$ (Aulakh et al., 2001; Christensen et al., 2003). There are studies that found positive correlations between radiation or net ecosystem production and $\mathrm{CH}_{4}$ flux (Whiting and Chanton, 1993; Joabsson and Christensen, 2001), although there are also studies that found the opposite (Mikkelä et al., 1995; Ström et al., 2005). Ström et al. explain the negative correlation of the $\mathrm{CH}_{4}$ oxidation rate, depending on the oxygen transport capacity of the plants. In general, we expect that there should be an effect of photosynthesis on the $\mathrm{CH}_{4}$ flux because plant photosynthates are an important carbon source for methanogens (Philippot et al., 2009). It is, nevertheless, hard to say how much the diurnal pattern is influenced by this. In our data we see that on average the maximum $\mathrm{CH}_{4}$ flux appears almost at the same time as the maximum $\mathrm{CO}_{2}$ uptake. The question, however, is if the response time between photosynthesis and excretion of root exudates to the production of $\mathrm{CH}_{4}$ could be that fast. Most studies that relate root exudation to $\mathrm{CH}_{4}$ flux or production did not measure in hourly resolution. Nevertheless, Aulakh et al. (2001) found a $\mathrm{CH}_{4}$ production peak 1 day after adding root exudates to pre-incubated clay soils, whereas Ström et al. (2005) found emission peaks for $\mathrm{CH}_{4}$ and $\mathrm{CO}_{2}$ more than 2 days after adding labeled acetate to soil with wetland plants in monoliths. Another reason why we assume that the diurnal 
pattern is mainly caused by the internal pressurized convective flow of the plants builds on the observation that there is still a diurnal pattern for $\mathrm{CH}_{4}$ flux visible in October: photosynthesis has come to an end, but the plants are still (partly) alive.

During winter, the daily pattern in the $\mathrm{CH}_{4}$ fluxes was no longer visible. Dead culms of reed are able to transport $\mathrm{O}_{2}$ into the soil and $\mathrm{CH}_{4}$ and $\mathrm{CO}_{2}$ from the soil to the atmosphere, but only by diffusion (Brix, 1989). During the winter months, correlations of gas fluxes with environmental variables were low. Nevertheless, the highest correlation was with soil temperature. This suggests that soil temperature played the dominant role during this period. Soil temperature influences microbial activity (Moore, 1994; Le Mer and Roger, 2001). It also influences respiration, which influences the availability of substrate needed for methanogenesis $\left(\mathrm{CO}_{2}\right.$, acetate; Christensen et al., 2003). Therefore, an increase in temperature leads to higher emissions. Water table height is known to have a large impact on $\mathrm{CH}_{4}$ fluxes (Moore and Knowles, 1989; Aerts and Ludwig, 1997; Grünfeld and Brix, 1999; Updegraff et al., 2001), but only for non-flooded peatlands. In our case, the impact was small because the water table was always above surface level $(5-40 \mathrm{~cm})$ so that the soil remained anoxic.

\section{3 $\mathrm{CO}_{2}$ flux patterns}

Also $\mathrm{CO}_{2}$ fluxes exhibited clear diurnal and seasonal patterns. The fluxes were mainly influenced by the presence of green plants (high negative correlation with global radiation) and temperature changes. A similar diurnal and seasonal variation was observed in a Phragmites wetland in northeast China based on EC measurements (Zhou et al., 2009). They also observed the highest $\mathrm{CO}_{2}$ uptake in July with $-13.6 \mathrm{~g} \mathrm{CO}_{2} \mathrm{~m}^{-2} \mathrm{day}^{-1}$, which is lower than our measured uptake of $-17.5 \mathrm{~g} \mathrm{CO}_{2} \mathrm{~m}^{-2} \mathrm{day}^{-1}$, and a small release of $\mathrm{CO}_{2}$ in winter, which is in the same range ( $2.6 \mathrm{~g} \mathrm{CO}_{2} \mathrm{~m}^{-2}$ day $^{-1}$ vs. $2.7 \mathrm{~kg} \mathrm{CO}_{2} \mathrm{~m}^{-2}$ day $^{-1}$ ) as our observations. The difference in July can be explained by the much higher soil and ambient temperature in the study by Zhou et al. (2009), which resulted in higher $R_{\text {eco }}$ relative to the increase in assimilation.

The $Q_{10}$ values based on soil temperature in the study by Zhou et al. (2009) are within the same range (4.1 in May to 1.8 in September-October) as what we found (3.93 in MayJune to 1.53 September-October). This number is still higher than the $Q_{10}$ value found by Mahecha et al. (2010) based on a global collection of FLUXNET data. A possible reason might be that we used soil temperature instead of air temperature. Soil temperature gave a much better fit in the regression and soil respiration is also expected to have a high contribution due to the high carbon content in the soil. But plant respiration also contributes a certain fraction and is more dependent on air temperature. Due to the almost permanent water logging at the study site, the difference between the ranges of air night temperatures and soil night temperatures was particularly large.

\subsection{Ecosystem as a carbon and greenhouse gas sink}

The yearly $\mathrm{CO}_{2}$ uptake was $894 \mathrm{~g} \mathrm{~m}^{-2} \mathrm{a}^{-1}$, and the $\mathrm{CH}_{4}$ emission $30 \mathrm{~g} \mathrm{~m}^{-2} \mathrm{a}^{-1}$. The $\mathrm{CO}_{2}$ uptake is almost 4 times higher than in a Phragmites wetland in China (Zhou et al., 2009). The difference could be explained by the lower temperature at our site, so that the respiration rate is lower. Our $\mathrm{CH}_{4}$ flux is in the same range as at sites with similar Phragmites densities (see above). More generally, northern fens show a wide variation in $\mathrm{CH}_{4}$ fluxes, from close to 0 to $300 \mathrm{~g} \mathrm{CH}_{4} \mathrm{~m}^{-2} \mathrm{a}^{-1}$, depending on temperature, water table and vegetation cover, among others (Lai, 2009; Kayranli et al., 2010). Our site is at the lower range of that spectrum.

Summing up $\mathrm{CO}_{2}$ and $\mathrm{CH}_{4}$ fluxes of our ecosystem leads to the net annual carbon uptake of $220 \mathrm{~g} \mathrm{C} \mathrm{m}^{-2}$, which is $26 \%$ of the GEP. It should be noted that the calculated respiration rate during daytime might be underestimated due to the plant-mediated gas transport. Brix et al. (1996) measured that around noon, 5 times more $\mathrm{CO}_{2}$ was transported from the soil to the atmosphere by Phragmites plants compared to the early evening. Because daytime respiration is only estimated from its nighttime relationship with soil temperature, respiration could be underestimated, and therefore the GEP as well. This would mean that the percentage of the GEP stored in the system would be lower than is given above. It is however, hard to say how much lower, since we cannot independently assess the respiration rate during daytime.

The carbon uptake at our site is much higher than the $65 \mathrm{~g} \mathrm{C} \mathrm{m}^{-2}$ (5\% of the GEP) measured in the Phragmitesdominated wetland in northeast China (Zhou et al., 2009; $\mathrm{CH}_{4}$ is not considered). But it is only half as high as the uptake estimated for a Phragmites-dominated wetland in Denmark (550 $\mathrm{g} \mathrm{C} \mathrm{m}^{-2} \mathrm{a}^{-1}, 47 \%$ of GEP; Brix et al., 2001). The temperature during the growing season was lower than in the Chinese wetland, on average even $10^{\circ} \mathrm{C}$ lower in July. Zhou et al. calculated a much higher $R_{\mathrm{eco}}$, which may have caused the difference. The wetland described by Brix et al. (2001) has a similar $R_{\text {eco }}$ to ours, but a $30 \%$ higher GEP, which explains the diverging findings. Our measured uptake of $65 \mathrm{~g} \mathrm{C} \mathrm{m}^{-2} \mathrm{a}^{-1}$ fits in the wide range of measured carbon exchange in northern peatlands: from an uptake of $220 \mathrm{~g} \mathrm{C} \mathrm{m}^{-2} \mathrm{a}^{-1}$ to a release of $310 \mathrm{~g} \mathrm{C} \mathrm{m}^{-2} \mathrm{a}^{-1}$ (Strack, 2008). In the long term, the uptake of northern peatlands is on average between $20-50 \mathrm{~g} \mathrm{C} \mathrm{m}^{-2} \mathrm{a}^{-1}$ (Strack, 2008). A longer measurement period may be needed however, to ensure that $\mathrm{C}$ uptake at our site falls indeed into this range.

\section{Conclusions}

Our $\mathrm{CH}_{4}$ fluxes show distinct diurnal cycles, but only in the period when living green plants were present. This strongly 
suggests that plant-mediated gas transport in Phragmites plays an important role regarding the emission of $\mathrm{CH}_{4}$ from a natural fen site in Federseemoor, southwest Germany. The convective flow within the plant is probably not solely driven by the humidity gradient between the interior of the plant and the ambient air (HIC theory). From our data it is more likely that global radiation plays a more significant role in creating a higher pressure inside the plant.

Our research site is a sink for both carbon $\left(-221 \mathrm{~g} \mathrm{C} \mathrm{m}^{-2} \mathrm{a}^{-1}\right)$ and greenhouse gases $\left(-52 \mathrm{~g} \mathrm{CO}_{2}\right.$ eq. $\left.\mathrm{m}^{-2} \mathrm{a}^{-1}\right)$ in the year studied. This is probably due to the high productivity of Phragmites plants, the high water table and the relatively cold climate, so that respiration rates are relatively low. Thereby, the low $\mathrm{CH}_{4}$ emission compared to other Phragmites wetlands can be explained by the high plant density in our system, which could reduce ebullition.

In general, wetland plants that can enhance gas transport, such as Phragmites, are important to consider for determining the impact of these wetlands on climate change. The role of environmental factors such as global radiation and relative humidity on the convective flow within Phragmites should be further investigated. This would be helpful in gaining more knowledge about the contribution of plant-mediated transport to net fluxes of $\mathrm{CH}_{4}$ and $\mathrm{CO}_{2}$.

Acknowledgements. We would like to thank Heidje Reinhard for her substantial contribution during the setup of the eddy covariance system, and Giani Gangloff and Jamie Smidt for their technical assistance in the field. We would also like to thank the Federal State of Baden-Württemberg (BWPLUS program) for their financial support that made this research possible.

Edited by: J. Middelburg

Reviewed by: T. Arkebauer and one anonymous referee

\section{References}

Aerts, R. and Ludwig, F.: Water-table changes and nutritional status affect trace gas emissions from laboratory columns of peatland soils, Soil Biol. Biochem., 29, 11-12, 1997.

Afreen, F., Zobayed, S. M. A., Armstrong, J., and Armstrong, W.: Pressure gradients along whole culms and leaf sheaths, and other aspects of humidity-induced gas transport in Phragmites australis, J. Exp. Bot., 58, 1651-1662, 2007.

Arkebauer, T. J., Chanton, J. P., Verma, S. B., and Kim J.: Field measurements of internal pressurization in Phragmites autralis (Poaceae) and implications for regulation of methane emissions in a midlatitude prairie wetland, Am. J. Bot., 88, 653-658, 2001.

Armstrong, J. and Armstrong, W.: Light-enhanced convective throughflow increases oxygenation in rhizomes and rhizosphere of Phragmites australis (Cav.) Trin. ex Steud, New Phytol., 114, 121-128, 1990.
Armstrong, J. and Armstrong, W.: A convective through-flow of gases in Phragmites australis (Cav.) Trin. ex Steud, Aquat. Bot., 39, 75-88, 1991.

Armstrong, J., Armstrong, W., and Becket, P. M.: Phragmites autralis: Venturi-and humidity-induced pressure flows enhance rhizome aeration and rhizosphere oxidation, New Phytol., 120, 197-207, 1992.

Armstrong, W., Armstrong, J., and Becket, P. M.: Pressurised aeration in wetland macrophytes: some theoretical aspects of humidity induced convection and thermal transpiration, Folia Geobot., 31, 25-36, 1996a.

Armstrong, W., Armstrong, J., and Becket, P. M.: Pressurised ventilation in emergent macrophytes: the mechanism and mathematical modelling of humidity-induced convection, Aquat. Bot., 54, 121-135, 1996b.

Aulakh, M. S., Wassmann, R., Bueno, C., and Rennenberg, H.: Impact of root exudates of different cultivars and plant development stages of rice (Oryza sativa L.) on methane production in a paddy soil, Plant Soil, 230, 77-86, 2001.

Bendix, M., Tornbjerg, T., and Brix, H.: Internal gas transport in Typha latifolia $\mathrm{L}$. and Typha angustifolia $\mathrm{L}$. 1. Humidity-induced pressurization and convective throughflow, Aquat. Bot., 49, 7589, 1994.

Bonn, A., Reed, M. S., Evans, C. D., Joosten, H., Bain, C., Farmer, J., Emmer, I., Couwenberg, J., Moxey, A., Artz, R., Tanneberger, F., von Unger, M., Smyth, M.-A., and Birnie, D.: Investing in nature: Developing ecosystem service markets for peatland restoration, Ecosystem Services, 9, 54-65, 2014.

Brix, H.: Gas exchange through dead culms of reed, Phragmites australis (cav.) Trin. ex Steudel, Aquat. Bot., 35, 81-98, 1989.

Brix, H., Sorrell, B., and Orr, P.: Internal pressurization and convective gas flow in some emergent freshwater macrophytes, Limnol. Oceanogr., 37, 1420-1433, 1992a.

Brix, H., Sorroll, B., and Schierup, H.: Gas fluxes achieved by in situ convective flow in Phragmites australis, Aquat. Bot., 54, 151-163, 1992b.

Brix, H., Sorrell, B. K., and Lorenzen, B.: Are Phragmitesdominated wetlands a net source or net sink of greenhouse gases?, Aquat. Bot., 69, 313-324, 2001.

Christensen, T., Ekberg, A., Ström, L., and Mastepanov, M.: Factors controlling large scale variations in methane emissions from wetlands, Geophys. Res. Lett., 30, 67.1-67.4, 2003.

Dacey, J.: Knudsen-Transitional Flow and Gas Pressurization in Leaves of Nelumbo, Plant Physiol., 85, 199-203, 1987.

Dacey, J. and Klug, M.: Methane efflux from lake sediments through water lilies, Science, 203, 1253-1255, 1979.

Falge, E., Baldocchi, D., Olson, R., Anthoni, P., Aubinet, M., Bernhofer, C., Burba, G., Ceulemans, R., Clement, R., Dolman, H., Granier, A., Gross, P., Grünwald, T., Hollinger, D., Jensen, N.O., Katul, G., Keronen, P., Kowalski, A., Lai, C. T., Law, B. E., Meyers, T., Moncrieff, J., Moors, E., Munger, J. W., Pilegaard, K., Rannik, Ü., Rebmann, C., Suyker, A., Tenhunen, J., Tu, K., Verma, S., Vesala, T., Wilson, K., and Wofsy S.: Gap filling strategies for defensible annual sums of net ecosystem exchange, Agr. Forest Meteorol., 107, 43-69, 2001.

Foken, T., Göckede, M., Mauder, M., Mahrt, L., Amiro, B., and Munger, J.: Handbook of Micrometeorology: A Guide for Surface Flux Measurement and Analysis, Kluwer Academic Publishers, Dordrecht, the Netherlands, 2004. 
Grünfeld, S. and Brix, H.: Methanogenesis and methane emissions: effects of water table, substrate type and presence of Phragmites australis, Aquat. Bot., 64, 63-75, 1999.

Grüttner, A. and Warnke-Grüttner, R.: Flora und Vegetation des Naturschutzgebietes Federsee (Oberschwaben) - Zustand und Wandel, LUWB, Karlsruhe, Germany, 1996.

Hendriks, D., van Huissteden, J., and Dolman, A.: Multi-technique assessment of spatial and temporal variability of methane fluxes in a peat meadow, Agr. Forest Meteorol., 150, 757-774, 2010.

IPCC: Anthropogenic and Natural Radiative Forcing, in: Climate Change 2013: The Physical Science Basis, Contribution of Working Group I to the Fifth Assessment Report of the Intergovernmental Panel on Climate Change, edited by: Stocker, T. F., Qin, D., Plattner, G.-K., Tignor, M., Allen, S. K., Boschung, J., Nauels, A., Xia, Y., Bex, V., and Midgley, P. M., 659-740, Cambridge University Press, Cambridge, United Kingdom and New York, USA, 2013.

Joabssen, A. and Christensen, T. R.: Methane emissions from wetlands and their relationship with vascular plants: an Arctic example, Glob. Change Biol., 7, 919-932, 2001.

Kankaala, P., Ojala, A., and Käki, T.: Temporal and spatial variation in methane emissions from a flooded transgression shore of a boreal lake, Biogeochemistry, 68, 297-311, 2004.

Kayranli, B., Scholz, M., Mustafa, A., and Hedmark, A.: Carbon storage and fluxes within freshwater wetlands: a critical review, Wetlands, 30, 111-124, 2010.

Kim, J., Billesbach, D. P., and Clement, R. J.: Diel variation in methane emission from a midlatitude prairie wetland: Significance of convective throughflow in Phragmites australis, J. Geophys. Res., 103, 28029-28039, 1998a.

Kim, J., Verma, S. B., and Billesbach, D. P.: Seasonal variation in methane emission from a temperate Phragmites-dominated marsh: effect of growth stage and plant-mediated transport, Glob. Change Biol., 5, 433-440, 1998b.

Kljun, N., Calanca, P., Rotach, M. W., and Schmid, H. P.: A simple parameterisation for flux footprint predictions, Bound.-Lay. Meteorol., 112, 503-523, 2004.

Koch, S., Jurasinski, G., Koebsch, F., Koch, M., and Glatzel, S.: Spatial variability of annual estimates of methane emissions in a Phragmites australis (Cav.) Trin. Ex Steud. dominated restored coastal brackish fen, Wetlands, 34, 593-602, 2014.

Lai, D. Y. F.: Methane Dynamics in Northern Peatlands: A Review, Pedosphere, 19, 409-421, 2009.

Le Mer, J. and Roger, P.: Production, oxidation, emission and consumption of methane by soils: A review, Eur. J. Soil Biol., 37, 25-50, 2001.

Lloyd, J. and Taylor, J. A.: On the temperature dependence of soil respiration, Funct. Ecol., 8, 315-323, 1994.

Mahecha, M. D., Reichstein, M., Carvalhais, N., Lasslop, G., Lange, H., Seneviratne, S. I., Vargas, R., Ammann, C., Arain, M. A., Cescatti, A., Janssens, I. A., Migliavacca, M., Montagnani, L., and Richardson, A. D.: Global convergence in the temperature sensitivity of respiration at ecosystem level, Science, 329, 838-840, 2010.

Mikkelä, C., Sundh, I., Svensson, B. H., and Nilsson, M.: Diurnal variation in methane emission in relation to the water table, soil temperature, climate and vegetation cover in a Swedish acid mire, Biogeochemistry, 28, 93-114, 1995.
Moore, T. R. and Knowles, R.: The influence of water table levels on methane and carbon dioxide emissions from peatland soils, Can. J. Soil Sci., 69, 33-38, 1989.

Moore, T. R.: Trace gas emissions from Canadian peatlands and the effect of climate change, Wetlands, 14, 223-228, 1994.

Nakai, T. and Shimoyama, K.: Ultrasonic anemometer angle of attack errors under turbulent conditions, Agr. Forest Meteorol., 162-163, 14-26, 2012.

Philippot, L., Hallin, S., Börjesson, G., and Baggs, E. M.: Biochemical cycling in the rhizosphere having an impact on global change, Plant Soil, 321, 61-81, 2009.

Reichstein, M., Falge, E., Baldocchi, D., Papale, D., Aubinet, M., Berbigier, P., Bernhofer, C., Buchmann, N., Gilmanov, T., Granier, A., Grünwald, T., Havránková, K., Ilvesniemi, H., Janous, D., Knohl, A., Laurila, T., Lohila, A., Loustau, D., Matteucci, G., Meyer, T., Miglietta, F., Ourcival, J.-M., Pumpanen, J., Rambal, S., Rotenberg, E., Sanz, M., Tenhunen, J., Seufert, G., Vaccari, F., Vesala, T., Yakir, D., and Valentini, R.: On the separation of net ecosystem exchange into assimilation and ecosystem respiration: review and improved algorithm, Glob. Change Biol., 11, 1424-1439, 2005.

Roulet, N.: Peatlands, carbon storage, greenhouse gases, and the Kyoto protocol: prospects and significance for Canada, Wetlands, 20, 605-615, 2000.

Salhani, N. and Stengel, E.: A comparative study of the gas exchange potential between three wetland species using sulfur hexafluoride as a tracer, Ecol. Eng., 18, 15-22, 2001.

Segers, R.: Methane production and methane consumption: a review of processes underlying wetland methane fluxes, Biogeochemistry, 41, 23-51, 1998.

Strack, M.: Peatlands and climate change, International Peat Society, Finland, 2008.

Ström, L., Mastepanov, M., and Christensen, T. R.: Species specific effects of vascular plants on carbon turnover and methane emissions from wetlands, Biogeochemistry, 75, 65-82, 2005.

Updegraff, K., Bridgham, S. D., Pastor, J., Weishampel, P., and Harth, C.: Response of $\mathrm{CO}_{2}$ and $\mathrm{CH}_{4}$ emissions from peatlands to warming and water table manipulation, Ecol. Appl., 11, 311326, 2001.

van der Nat, F. W. A. and Middelburg, J. J.: Methane emission from tidal freshwater marshes, Biogeochemistry, 49, 103-121, 2000.

van der Nat, F. W. A., Middelburg, J. J., van Meteren, D., and Wielemakers, A.: Diel methane emission patterns from Scirpus lacustris and Phragmites australis, Biogeochemistry, 41, 1-22, 1998.

Webb, E. K., Pearman, G. I., and Leuning, R.: Correction of flux measurements for density effects due to heat and water vapour transfer, Q. J. Roy. Meteorol. Soc., 106, 85-100, 1980.

Whiting, G. J. and Chanton, J. P.: Primary production control of methane emission from wetlands, Nature, 364, 794-795,1993.

Wilczak, J. M., Oncley, S. P., and Stage, S. A.: Sonic anemometer tilt correction algorithms, Bound.-Lay. Meteorol,, 99, 127-150, 2001.

Zhou, L., Zhou, G., and Jia, Q.: Annual cycle of $\mathrm{CO}_{2}$ exchange over a reed (Phragmites australis) wetland in Northeast China, Aquat. Bot., 91, 91-98, 2009. 